\title{
PREDIKSI KOLEKTIBILITAS PEMBIAYAAN SEGMEN USAHA KECIL DAN MENENGAH (UKM) MENGGUNAKAN NEURAL NETWORK
}

\author{
Fakultas Teknologi Informasi \\ Universitas Islam Kalimantan Muhammad Arsyad Al Banjari Banjarmasin \\ Muhammad Hasbi \\ mhasbi.mm@gmail.com
}

\begin{abstract}
ABSTRAK
Pembiayaan yang disalurkan oleh bank kepada nasabah usaha kecil dan menengah di Indonesia memiliki kriteria tersendiri, umumnya perusahaan ini belum mampu membuat laporan keuangannya dengan standar akuntansi yang berlaku, sehingga diperlukan kemampuan seorang analis yang dapat melakukan verifikasi terhadap data keuangan yang diterimanya. Data-data keuangan dan rasio keuangan ini kemudian diolah kedalam pengolahan data maining dengan menggunakan algoritma Neural Network (NN) untuk memprediksi kolektibilitas nasabah pembiayaan dengan akurasi yang terbaik sehingga akan diketahui model dan parameter yang lebih akurat untuk mengetahui kondisi keuangan nasabah dalam mendukung pengambilan keputusan pembiayaan. Pada pengujian type data I, menggunakan seluruh dataset yaitu data keuangan dan rationya dengan menggunakan seleksi atribut diperoleh akurasi sebesar 88,58\%. Dengan type data II yaitu hanya menggunakan data ratio keuangan dengan seleksi terpilih 16 atribut dan x-validasi 5 split, diperoleh akurasi terbaik 89,84\%. Dengan menggunakan data type II dilakukan uji coba data testing berupa ratio keuangan projection diperoleh akurasi $93,81 \%$. Dan dengan data type III yaitu mengelompokkan atribut kolektibilitas menjadi atribut NPF sesuai dengan katagorinya diperoleh hasil akurasi 95,55\%.
\end{abstract}

Kata Kunci: Neural Network, Prediksi Kolektibiltas, Usaha Kecil dan Menengah, Analisa pembiayaan/kredit.

\section{PENDAHULUAN}

Kemampuan pengembalian pembayaran angsuran pembiayaan merupakan salah satu penyebab pembiayaan bermasalah di perbankan hal ini disebabkan oleh beberapa faktor seperti penurunan pendapatan usaha, faktor makro ekonomi atau faktor kesalahan dalam melakukan analisa pembiayaan terutama dalam mengestimasi ratio keuangan dimasa yang akan datang.

Adapun non performing financing (NPF) industri perbankan syariah mencetak rasio tertinggi dalam tiga tahun terakhir ini. Pada Juni 2014, NPF berada di level 3,48\%. Kekhawatirkan peningkatan NPF membuat bank syariah semakin mengerem lagi 
ekspansi. Pada Juni 2014, rasio NPF bank umum syariah dan unit usaha syariah mencapai $3,48 \%$, meningkat 84 basis poin (bps) dari posisi 2,64\%. Sebelumnya, pada 2010, NPF industri bank syariah pernah mencapai $3,02 \%$.

Penggunaan analisis rasio untuk melakukan interpretasi dan menganalisis laporan keuangan akan menggunakan ukuran tertentu yg disebut rasio. Rasio merupakan bentuk rumusan matematis yg menunjukkan hubungan di antara angka tertentu yang dapat digunakan untuk menjelaskan hubungan antara dua macam data keuangan.

Pembiayaan yang disalurkan oleh bank kepada nasabah usaha kecil dan menengah (UKM) di Indonesia memiliki kriteria tersendiri, umumnya perusahaan ini belum mampu membuat laporan keuangannya dengan standar akuntansi yang berlaku, sehingga diperlukan kemampuan seorang analis yang dapat melakukan verifikasi terhadap data keuangan yang diterimanya melalui pengecekan silang data keuangan, pengecekan di lapangan dengan wawancara langsung terhadap suplayer maupun pelanggan pengusaha tersebut.

Data-data keuangan yang telah dianalisa dibuat menjadi rasio-rasio keuangan ini kemudian diolah ke dalam pengolahan data maining dengan menggunakan algoritma sehingga akan diketahui algoritma yang lebih akurat untuk mengetahui ratio keuangan nasabah dalam mendukung pengambilan keputusan pembiayaan. Karena itu perlu di buktikan, bahwa algoritma Neural Network (NN) yang lebih akurat dalam memprediksi kolektibilitas nasabah UKM dalam mendukung pengambilan keputusan pembiayaan.

\section{METODE PENELITIAN}

Terdapat banyak algotrima yang dapat dipakai untuk memprediksi analisa pembiayaan namun belum diketahui algoritma manakah yang memiliki kinerja lebih akurat untuk data nasabah UKM. Sehingga perlu masing-masing algoritma diuji untuk mengetahuinya. Metode yang diusulkan adalah metode perbandingan tingkat akurasi dari algoritma yang bisa digunakan untuk prediksi kolektibilitas. Algoritma yang akan diuji adalah Neural Network yang digunakan untuk memprediksi data ratio keuangan nasabah terhadap kolektibilitas nasabah. Algoritma akan implementasikan dengan menggunakan RapidMiner 5.3.015.

Evaluasi dilakukan dengan mengamati hasil prediksi data keuangan dan ratio keuangan dari penerapan Neural Network. Pengukuran kinerja dilakukan dengan menghitung akurasi dari prediksi kolektibilitas nasabah pembiayaan. Semakin besar nilai akurasi dari masing-masing parameter kinerja ini menyatakan semakin dekat nilai prediksi dengan nilai sebenarnya. Dengan demikian dapat diketahui parameter atau model mana yang lebih akurat.

\section{PEMBAHASAN}

Algoritma BP-NN akan diterapkan pada data ratio keuangan dan data keuangan, melalui model simulasi. Data yang digunakan sebagai data training, yaitu data keuangan usaha kecil dan menegah 
yang telah menjadi nasabah pembiayaan dengan data kolektibitas terendah yang pernah terjadi sampai dengan bulan Desember 2014.

Setiap data akan di training dengan beberapa perubahan parameter dan dievaluasi dengan akurasi. Setiap kali hasil evaluasi akan dicatat, semakin besar nilai akurasi dari masing-masing parameter kinerja, menyatakan semakin dekat nilai prediksi dengan nilai sebenarnya. Dengan demikian dapat diketahui algoritma BP-NN dengan parameter mana yang lebih akurat. Algoritma yang akan diuji dalam penelitian ini adalah BP-NN dengan menggunakan beberapa parameter, yaitu pengujian dengan seluruh data training, pemisahan data training atribut history ratio keuangan dengan data testing atribut projection data ratio keuangan dan pengelompokan berdasarkan klasifikasi NPF. Operator yang digunakan yaitu operator seleksi atribut dan $\mathrm{x}$-validation.

Hasil pengujian data keuangan dan data ratio keuangan masing-masing usaha kecil dan menengah yang telah ditraining dengan menggunakan parameter yang telah dijelaskan sebelumnya, menghasilkan; Pengujian type data I, menggunakan seluruh dataset yaitu data keuangan dan rationya dengan menggunakan seleksi atribut diperoleh akurasi sebesar $88,58 \%$. Type data II, hanya menggunakan data ratio keuangan dengan seleksi terpilih 16 atribut dan $\mathrm{x}$ validasi 5 split, diperoleh akurasi terbaik $89,84 \%$. Dengan menggunakan data type II dilakukan uji coba data testing berupa ratio keuangan projection diperoleh akurasi 93,81\%. Dan dengan data type III yaitu mengelompokkan attribut kolektibilitas menjadi atribut NPF sesuai dengan katagorinya diperoleh hasil akurasi 95,55\%.

\section{KESIMPULAN}

Dalam penelitian ini dilakukan pengujian dengan menggunakan model algoritma back propagation neural network dengan fungsi seleksi atribut dengan menggunakan data keuangan dan data ratio keuangan nasabah pembiayaan segmentasi usaha kecil dan menengah untuk dapat memprediksi kolektibilitas nasabah pembiayaan. Pengujian dengan mencoba beberapa pembagian type data untuk mendapatkan prediksi yang paling akurat.

Pengujian type data I, menggunakan seluruh dataset yaitu data keuangan dan rationya dengan menggunakan seleksi atribut diperoleh akurasi sebesar $88,58 \%$. Type data II, hanya menggunakan data ratio keuangan dengan seleksi terpilih 16 atribut dan $\mathrm{x}$ validasi 5 split, diperoleh akurasi terbaik $89,84 \%$. Dengan menggunakan data type II dilakukan uji coba data testing berupa ratio keuangan projection diperoleh akurasi 93,81\%. Dan dengan data type III yaitu mengelompokkan attribut kolektibilitas menjadi atribut NPF sesuai dengan katagorinya diperoleh hasil akurasi 95,55\%.

Dari hasil pengujian model algoritma di atas dapat disimpulkan bahwa algoritma back propagation neural network dengan seleksi atribut dapat digunakan sebagai solusi dalam memprediksi 
kolektibitas dan NPF nasabah pembiayaan dengan lebih akurat.

\section{DAFTAR PUSTAKA}

Bisnis.com, 2014, http://bisnis.com/

Detikfinance, 2014 , http://detik.com/detikfinance/

Departemen Pendidikan Nasional, Pusat Bahasa. 2008. Kamus Bahasa Indonesia. Jakarta.

Desei Sulistiowati, 2009, Estimasi Kolektibilitas, Performance Kredit dan Perbandingan Matriks Transisi pada Kredit Perbankan Tahun 2008, Jakarta, Fakultas Ekonomi, Pasca Sarjana Universitas Indonesia

Gang Wang, Jian Ma, 2012, A hybrid ensemble approach for enterprise credit risk assessment based on SVM, Elsevier Ltd. All rights reserved.

Ginting Ramlan, DR. S.H., LL.M., 2005, Pengaturan Pemberian Kredit Bank Umum, Diskusi Hukum "Aspek Hukum Perbankan, Perdata, dan Pidana Terhadap Pemberian Fasilitas Kredit Dalam Praktek Perbankan di Indonesia", Jakarta

Gnana Sheela K and S.N Deepa, "Analysis of Computing Algorithm using Momentum in Neural Networks," Journal of Computing, vol. 3, no. 6, pp. 163-166, June 2011.
Jeff Heaton, Introduction to Neural Networks with Java, Second Edition ed., Kerrin Smith, Ed. St. Louis, United States of America: Heaton Research, Inc, 2008

Kamaludin dan Rini Indriani, 2012, Manajemen Keuangan "Konsep Dasar dan Penerapannya", Cetakan Ke-7, CV. Mandar Maju, Bandung.

Kasmir, 2010, Analisis Laporan Keuangan, Cetakan Ke-6, PT. Rajagrafindo Persada, Jakarta.

Kin Keung Lai1,2, Lean Yu 2,3, Ligang Zhou2, and Shouyang Wang1,3, 2006, Credit Risk Evaluation with Least Square Support Vector Machine, IEEE

Luh Gede Meydianawathi. 2007. Analisis Perilaku Penawaran Kredit Perbankan Kepada Sektor UMKM Di Indonesia (20022006). Buletin Studi Ekonomi Volume 12 Nomor 2 Tahun 2007.

Paulius Danenasa, Gintautas Garsvab, Saulius Gudasc, 2011, Credit Risk Evaluation Model Development Using Support Vector Based Classifiers, International Conference on Computational Science, ICCS

Peraturan Bank Indonesia Nomor 14/22/PBI/2012, Tentang Pemberian Kredit Atau Pembiayaan Oleh Bank Umum Dan Bantuan Teknis Dalam Rangka Pengembangan Usaha Mikro, Kecil, Dan Menengah 
Shu-Fang Zhao, Li-Chao Chen, 2009, The BP Neural Networks Applications In Bank Credit Risk Management System, IEEE Institute of Computer Science and Technology, Taiyuan University of Science and Technology, Taiyuan, Shanxi 030024, China.

Siang Jong Jek, Jaringan Syaraf Tiruan dan Pemrogramannya, 2nd ed. Yogyakarta: Penerbit Andi, 2009.

Suyanto, 2007, Artificial Intelligenc: Searching, Reasoning, Planning, and Learning. Bandung: Penerbit Informatika.

Suyanto, 2008, Soft Computing: Membangun Mesin Ber-IQ Tinggi. Bandung, Jawa Barat, Indonesia: Informatika. 